\title{
Consumer perception of Petit-Suisse cheese: identifying market opportunities for the Brazilian dairy industry
}

\author{
Fernanda Romano TORRES ${ }^{1 *}$ (D), Hugo Leandro Azevedo da SILVA', Camila Sampaio CUTRIM ${ }^{1}$, \\ 'Marco Antonio Sloboda CORTEZ'
}

\begin{abstract}
The dairy market is hugely competitive, with dairy industries always looking for new products to reach the consumer. Projective techniques, such as the Completion task, are great allies in this process, as they identify consumer needs and expectations, which helps in developing brand new, more competitive products. Petit-Suisse cheese is a product which is well established in the Brazilian dairy market; however, its consumption is restricted to children and has few sales variations. The objective of the present work was to investigate the consumers' perception about Petit-Suisse and to identify possibilities of market expansion for this product category, through the technique of Completion task. According to the participants, Petit-Suisse is a widely accepted product, and its recognition was strongly related to the brand. Besides, although considered a product intended primarily for children, as a snack option, there is a substantial market possibility for the consumption of this product by other groups. Completion task made it possible to identify that there are different aspects of Petit-Suisse cheese, like flavor, composition and functional appeal that can still be explored by the dairy industry in making more competitive products on the market.
\end{abstract}

Keywords: dairy; consumers; projective techniques; sensory analysis; Petit Suisse.

Practical Aplication: This study approaches the application of Completion Task, a projective technique in the sensory analysis, to understand consumers' perceptions of Petit-Suisse cheese and to identify market options for the dairy industry. Consumers perceptions provided insights into targeting new versions of the product not available on the market and identified negative consumer perceptions about the product that can be a critical point in reaching a larger market. Therefore, it is important to apply these techniques as validation of its use and importance as a tool in the development of new products or improvement of existing products.

\section{Introduction}

Dairy products are widely consumed in different countries (Food and Agriculture Organization of the United Nations, 2019). One of these dairy products is cheese, which is an excellent source of protein, lipids, vitamins, and minerals and has a wide variety all over the world (Johnson, 2017; Santiago-López et al., 2018).

In Brazil, one of the five most produced cheeses is Petit-Suisse cheese. This is one of the greatest growing cheeses between 2007 and 2011, reaching 54.5 thousand tons, an increase of $102.1 \%$ (Lopes et al., 2018).

Petit-Suisse cheese is a lightly sour and soft cheese, added or not with other ingredients such as fruit pulp or sugar (Sarmento et al. 2018). It is usually consumed as a dessert and is designed to target children. However, this type of cheese is accepted by consumers of all ages and has a potential consumption to be exploited for adults (Veiga et al., 2000; Cardarelli et al., 2008; Esmerino et al., 2015).

In Brazil, Petit-Suisse is usually consumed as a dessert and is designed to target children. However, this type of cheese is accepted by consumers of all ages and has a potential consumption to be exploited for adults (Veiga et al., 2000; Cardarelli et al., 2008; Esmerino et al., 2015).
The dairy market is exceptionally competitive, and the industries need to reinvent themselves to arouse consumer interest. Industries must understand the needs and expectations of the different consumers' groups in order to direct the development of their products. In this way, it is the consumer himself who defines the parameters of product quality (Busse \& Siebert, 2018; Hovart et al. 2019).

The food characteristics and the consumer experiences in the moment of ingestion are not the only factors that influence consumer's food choice. Other factors, as the particular opinion of the consumer about nutritional characteristics or composition of the product, safety, its trade or price have a significant influence at the time of the purchase decision (Lin et al., 2019; Songsamoe et al., 2019).

An analysis carried out by the Nielsen Institute between 2011 and 2013 revealed that, of all new food products launched in the Western European markets, $76 \%$ did not stay in the market for at least one year, of which $45 \%$ remained for less than six months (Dijksterhuis, 2016). One of the main causes for these high failure rates is that product development is driven by technical 
feasibility, disregarding consumer acceptance and preference (Stolzenbach et al., 2013; Bimbo et al., 2017).

Projective techniques are qualitative sensory methods to find out consumers' motivations, perceptions, beliefs and attitude of a product, revealing their non-conscious or not openly accepted motivations. (Gambaro, 2018). These techniques apply unstructured and ambiguous stimulus, which make more natural to the consumers express their opinion, point of view, motivation, attitudes and may be divided into five categories: word association, completion, construction, choice ordering and expressive techniques (Donoghue, 2000; Eldesouky et al., 2015; Pinto et al., 2018).

Currently, these methodologies have been applied in foodrelated research and are excellent tools to understand the consumer market and the direction of news products creation (Pacheco et al., 2018; Pinto et al., 2018; Rocha et al. 2018; Rojas-Rivas et al., 2018; Sass et al., 2018; Judacewski et al., 2019; Meyerding et al., 2019). Among these techniques, the Completion task stands out because it enables a higher projection of consumers' innermost feeling and thoughts associated to the fact that the researchers can directly assess the consumers' attention to specific aspects (Vidal et al., 2013). Completion task provides an incomplete sentence, story, argument, or conversation and asking to the interviewed to complete it according to their feelings and perceptions (Donoghue, 2000; Gambaro, 2018).

As considering the importance of cheeses for the Brazilian market and the continuous growth of competitors, it is crucial to the industry to understand the consumers' behavior and beliefs of Petit-Suisse to identify new market opportunities to explore. Thus, the present study aimed to utilize an online questionnaire with the projective technique of completion task to investigate consumer's knowledge about Petit-Suisse and the perceptions involved in the process of consumption and purchase to identify theirs needs which can enable the dairy industry to expand its market opportunities.

\section{Materials and methods}

The online questionnaire obtained 263 respondents: 78\% women and 22\% men, aged between 18 and 65 years.

The participants were recruited by e-mail, and invitations via social networks answered an online questionnaire and performed the completion task. At the beginning of the questionnaire, there was a brief explanation about the study, data confidentiality, voluntary participation, and e-mail contact for any questions. As the present study was not intended to represent a specific segment of the market population but explored the associations of consumers in general about the Petit-Suisse and their motivation to buy this kind of product, a convenience sample was chosen. Convenience sampling is applied in qualitative research to get an approximation to a specific topic, and it is not intended to represent the entire market population (Vidal et al., 2013).

The online questionnaire was developed using Google Forms: a free tool designated for online surveys. The survey was divided into three different parts. The first part of the questionnaire consisted of brief questions about demographic data (gender, age, education level, children in the family) and a question about the frequency of dairy products consumption.
In the second part, the objective was to verify the degree of consumers knowledge and perception about Petit-Suisse. For this, a picture of the product was presented, and interviewed were requested to answer what's product was that if they knew what Petit-Suisse cheese was and if they liked it. Then, pictures of commercial brands of Petit-Suisse cheeses were presented. The respondents were then asked again if they knew the products and if they liked them. After that, the respondents were questioned about frequency of consumption, time of the day to consume, and target audience.

The last step was the Completion Task combined with the use of stimuli, in which the respondents were requested to complete the dialogue by the statement: "Please read the dialogue and complete the phrase." The dialogues were designed to guide respondents' answers to specifics aspects (Vidal et al., 2013). The first stimulus was related to identifying the motivation of purchase decision. The following picture of the dialogue sought to know why people do not buy the product even if they like it. In the last one, respondents were stimulated to answer which condition would make them buy the product. Figure 1 displays the different stimuli provided.
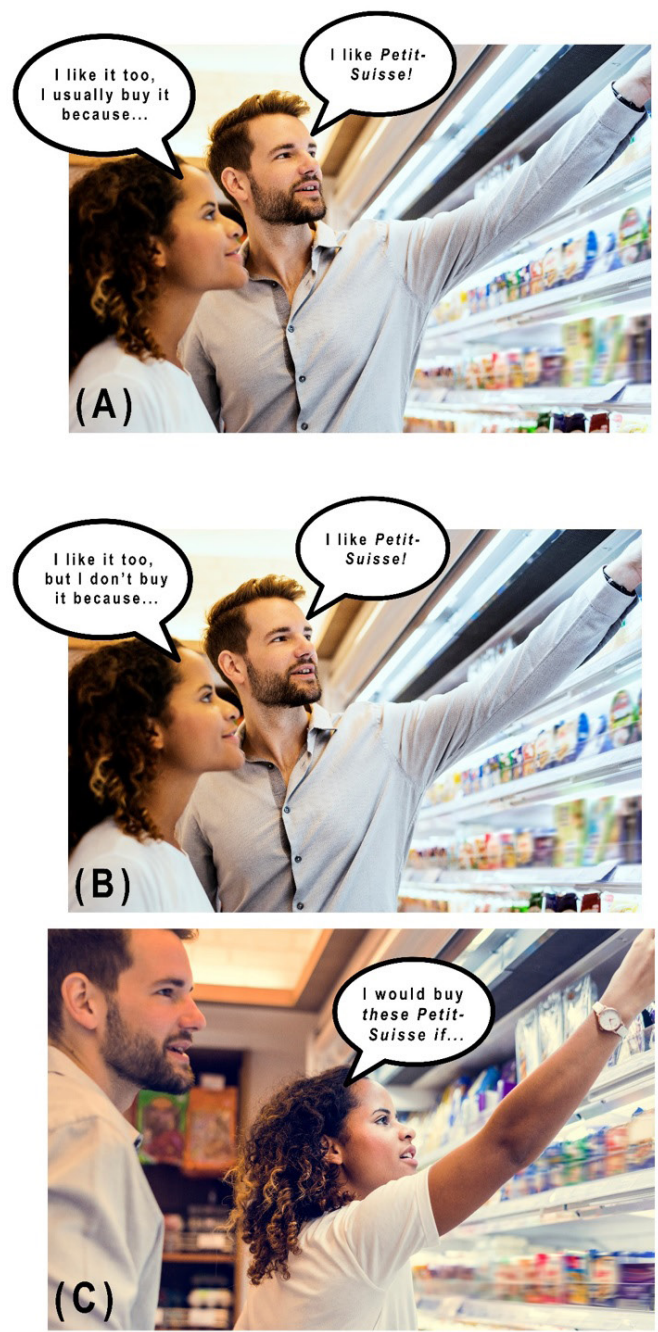

Figure 1. Representation of the stimuli used in the Completion Task. (A) First stimulus. (B) Second stimulus. (C) Third stimulus. 
The data gained by the completion task in the online questionnaire were analyzed as described by Eldesouky et al. (2015) and Viana et al. (2016). The phrases and words mentioned in the quiz were identified by using the triangulation technique, in which three experienced researchers analyzed the participant's responses and grouped them into categories based on personal interpretation. The classifications performed by the researchers were later combined to establish the final categories. After that, each category was analyzed based on its frequency of mention. The analysis just considered those categories which represented more than $5 \%$ of the answers. This cut point was picked to prevent the loss of a significant amount of information (Guerrero et al., 2010).

\section{Results}

In the first question, when participants were asked if they knew what a Petit-Suisse cheese was, $62.74 \%$ affirmed to know, while $37.26 \%$ were unaware of this product. When asked if they liked Petit-Suisse, $46.77 \%$ responded that they liked the product while the rest did not like it (18.25\%) or did not know if they liked it (34.98\%). In the next step, a picture of Petit-Suisse cheese was shown, and they had to answer the same questions. In this case, $98.10 \%$ of the participants responded that they knew the product, and $73.38 \%$ responded that they liked it. Figure 2 displays the results of the first question.

Figure 3 presents the results obtained in the second part of the questionnaire, in which the interviewees were asked about the consumption of Petit-Suisse cheese. Most of the respondents affirmed that they did not consume this product $(51.33 \%)$. Those who claimed, they consumed $(48,67 \%)$, declared they do it rarely (38.02\%). As asked the type of meal during which this cheese was consumed, the snack was the most frequent answer (59.32\%), followed by breakfast (20.91\%) and dessert (19.39\%). The last question was about what kind of consumer should eat Petit-Suisse cheese. Most of the respondents indicated children as primary consumers $(86.31 \%)$. Adults, Teenagers, and seniors were pointed out by $6.46 \%, 5.32 \%$, and $1.90 \%$ of the participants, respectively.

Table 1 displays the categories identified in the first stimulus of the completion task ("I usually buy it because...."). A relevant

\section{(A)}

Without the picture

Do you know what a Petit-suisse cheese is?

Do you like Petit-suisse cheese?

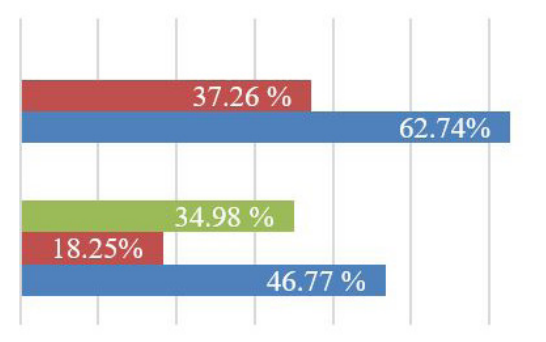

I don't know $\mathbf{n}$ No $\quad$ Yes

(B)

\section{With the picture}

Do you know what a Petit-suisse cheese

Do you like Petit-suisse cheese?

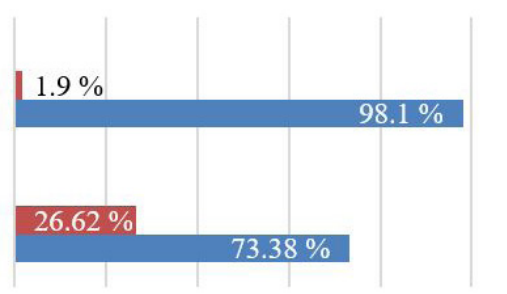

\section{I don't know $\square$ No $\square$ Yes}

Figure 2. Results of online questionnaire about consumers' Petit-Suisse cheese knowledge. With and without the product's picture.

Table 1. Categories identified in the completion task for the first stimulus related to identify the motivation of purchase decision of Petit-Suisse.

\begin{tabular}{clc}
\hline Category & \multicolumn{1}{c}{ Examples } & Percentage of mention (\%) \\
\hline Acceptance & I like it. It is tasty, it is good & 52.85 \\
Healthiness & It is nutritious, it is healthy, it is light, it feeds me & 10.27 \\
Have children & My children like it, my granddaughter like it, the kids like it, my family like it & 8.75 \\
Would not buy it & I do not buy it, I do not like & 9.51 \\
Affective memory & It reminders my childhood to me, it tastes like childhood & 7.98 \\
\hline
\end{tabular}


Table 2. Categories identified in the completion task for the second stimulus related to identify the motivation of not purchase Petit-Suisse.

\begin{tabular}{ll}
\hline \multicolumn{1}{c}{ Category } & \multicolumn{1}{c}{$\begin{array}{c}\text { Examples } \\
\text { mention (\%) }\end{array}$} \\
\hline $\begin{array}{l}\text { Product High price } \\
\text { Not healthiness aspect }\end{array}$ & $\begin{array}{l}\text { It is expensive; It is expensive to eat daily; it is expensive and a small portion. } \\
\text { It is not healthy. It is bad for my health, there is no nutritional value, I prefer more healthy } \\
\text { food }\end{array}$ \\
$\begin{array}{ll}\text { High sugar content, it is not a "diet" food } \\
\text { It is intended to children }\end{array}$ & It is for children, I don't have children, It is baby food, I'm an adult \\
$\begin{array}{l}\text { Don't like the product } \\
\text { Additives and preservatives }\end{array}$ & I don't like it. My children don't like it anymore \\
$\begin{array}{l}\text { It has a lot of additives, It contains additives/preservatives, It contains food coloring } \\
\text { Fattening }\end{array}$ & It gets fat, it contains too much fat, I'm on a diet, It contains too many calories \\
Preference for others products & I prefer to buy another product that I like more, I prefer to buy a product with better \\
& nutritional value, I prefer other dairy products \\
It is an industrialized product & It is artificial, It is ultra-processed, It is an industrialized product, I prefer natural food
\end{tabular}

(A)

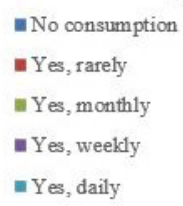

Consumption and its Frequency
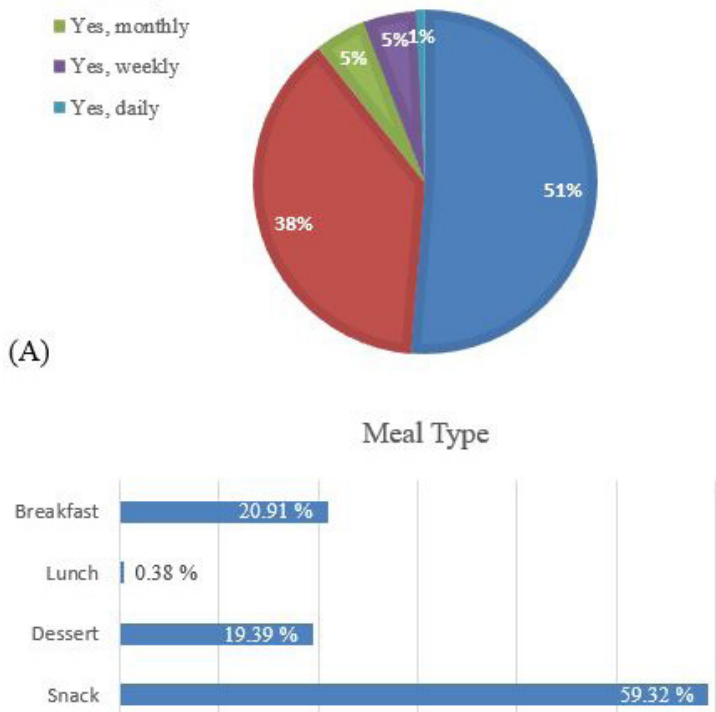

(B)

- Consumers

Target Consumers

\section{- Children \\ - Teenager \\ Adults \\ - Senior}

(C)

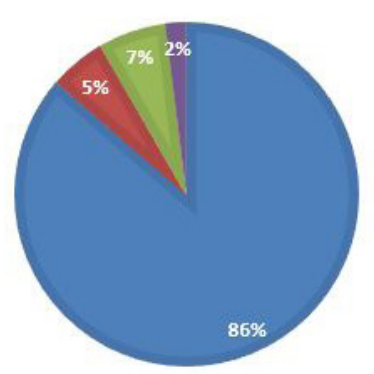

Figure 3. Results of online questionnaire about Petit-Suisse cheese consumption: (A) consumption frequency (B) meal type (C) target consumers. percentage of participants $(52.85 \%)$ mentioned the category "Acceptance." The respondents quoted the other categories: "Healthiness," "Have children," and "Affective Memory" with similar frequencies $(10.27 \%, 8.75 \%$, and $7.98 \%$, respectively). It is essential to point out that although the stimulus aimed to get positive aspects to buy the product, some consumers $(9.51 \%)$ pointed out that would not buy it.

Table 2 presents the categories obtained from the second stimulus ("I like it too, but I do not buy it because..."). This stimulus aimed to get the negative aspects, and then more categories were flagged. The central negative aspect mentioned by most for the respondents was the "High price" of Petit-Suisse cheese $(22.81 \%)$, followed by "Unhealthy" (13.69\%), "Sugar content" (11.03\%), "Intended to children" (9.89\%), "Don't like the product" (7.89\%), "Presence of additives and preservatives" (6.84\%), "Fattening" (6.08\%), "Preference for others products" (6.08\%), and "Industrialized product" (5.70\%).

In the last stimulus ("I would buy this Petite Suisse if..."), the participants had to indicate in which conditions they would buy the product. A "Cheaper price" was the most mentioned condition (22.05\%). The other relevant conditions were: "More Natural Product" (13.31\%), "More product options" (11.03\%), "Healthiness" (10.65\%), "Packing suitability" (8.75\%), "Children in the family" (8.37\%) and "Sugar Content" (7.60\%) as displayed in Table 3.

\section{Discussion}

The data obtained from the online questionnaire provide essential information about consumer perceptions and knowledge about Petit-Suisse cheese. According to the Brazilian legislation, in the technical regulation of identity and quality of Petit-Suisse, this is defined as "fresh cheese not matured, obtained by coagulation of milk with rennet or specific enzymes or specific bacteria, either added or not of other food substances" (Brasil, 2000). However, the responses to the online questionnaire highlighted that consumers are not familiar with the product and do not know that it is a cheese. The issue related to product knowledge displays the unfamiliarity of the public with the product. As comparing the answers obtained in two moments (without 
Table 3. Categories identified in the completion task for the third stimulus, stimulated to answer which condition consumers would buy Petit-Suisse.

\begin{tabular}{lll}
\hline \multicolumn{1}{c}{ Category } & \multicolumn{1}{c}{$\begin{array}{c}\text { Percentage of } \\
\text { mention (\%) }\end{array}$} \\
\hline Price & $\begin{array}{l}\text { If it were cheaper, If it wasn't so expensive, it was in a sale, if it came with more product } \\
\text { considering its price }\end{array}$ & 22.05 \\
More natural product & If it was more natural, If it was less artificial, If it didn't contain additives/preservatives \\
$\begin{array}{l}\text { A wider variety of flavors and } \\
\text { versions of this products }\end{array}$ & If there were more flavors options, If it was light/diet/organic/lactose-free \\
Healthiness & If it were healthy, If some research pointed out it benefits, If it brought benefits to my \\
& $\begin{array}{l}\text { health } \\
\text { Packing suitability }\end{array}$ & If the packing was larger, If the packing was intended to adults \\
$\begin{array}{l}\text { Children in the family } \\
\text { Sugar Content }\end{array}$ & If I had children, If more children went to my home, If I had grandchildren & 13.31 \\
\hline
\end{tabular}

the picture and with the picture), the results changed. That is, after the exposition of the participants to the product's picture in the way it is commercially found, the number of positive responses to the questions: "Do you know what Petit-Suisse is?", and "Do you like Petit-Suisse?" increased significantly in around $55 \%$. This result suggests that in this niche of the Brazilian market, the brand is stronger than the sales denomination. Lopes et al. (2018) describe a similar result. The authors performed a test with and without information and observed an increase in the number of consumers who correctly identified the Petit-Suisse product after being exposed to images of their packaging. Guerrero (1995) state that of all the information present on the packaging, the brand is the most important and that most influences the decision of the consumer.

As for the perception of the product, for most of the participants, this is a product intended for the infantile public. This perception that Petit-Suisse cheese is primarily intended to be consumed by children is widespread in the Brazilian market. It is already customary to offer Petit-Suisse cheese for children of different age groups. A study by Toloni et al. (2014) in public/philanthropic daycare centers showed that the consumption of this product started at an age between 0-6 months and that between 12 and 36 months of age, 97.8\% of the children had already introduced Petit-Suisse cheese in their diet. In addition, most of participants to our research replied that Petit-Suisse cheese is consumed as an option for a snack (59.32\%), breakfast (20.91\%), and dessert (19.39\%). These data corroborate with the results of Veiga et al. (2000), who indicate that Petit-Suisse has excellent acceptance in Brazil and is consumed in the form of dessert.

The questionnaire raised another critical question: although $73 \%$ of respondents say they like the product, only $48.67 \%$ consume it. This information can be better understood when we analyze the results obtained with the Completion task. Through the first stimulus of the Completion Task, it was possible to identify what leads consumers to buy it. The main reason is the acceptance of the product: the participants buy Petit-Suisse cheese because they like it (52.85\%). A part of the respondents (10.27\%) consider the Petit-Suisse cheese healthy food and buy it for this reason. In recent decades, consumer interest in health, and healthy products has been growing, directing companies to invest in products that have this appeal: products perceived as healthy by consumers are more widely accepted and thriving in the market (Bimbo et al., 2017).

The other motivations for buying raised were "Have children in the family" (8.75\%) and "Affective Memory" (7.98\%), where the participants affirmed that the product brings memories of childhood. Both motivations of purchase reinforce the idea that Petit-Suisse cheese is intended for children and consumed only at this stage. However, it is essential to note that, although cited, these were not the categories that stood out most in the study. These results open a market possibility to be explored, which includes consumption of Petit-Suisse cheese also by adults. In the study by Lopes et al. (2018), with adults ranging from 18 to 25 years, only $20 \%$ of the respondents consumed the product monthly. In France, Petit-Suisse cheese is available as a white cheese option, without the addition of fruit or sugar preparations, and the frequency of consumption of this type of product is on average once a week by $31 \%$ of adults (Cesbron-Lavau et al., 2017). How the consumer evaluates and considers the product is the result of their culture and eating habits, which are established in childhood and are modified at the onset of life. In this way, the decision to choose the food can be based on their health, desire, beliefs, convenience, press, or familiarity (Johansen et al., 2011).

The second stimulus aimed to understand what reasons lead consumers not to buy the product. This stimulus provided us with a greater variety of categories, the reasons being quite different. The main category, with a significant difference for the others, was the "High price of the product" (22.81\%). Probably this perception of expensive is related to the small portions that are marketed the product, usually around $40 \mathrm{~g}$. Studies conducted with different product types highlighted that the price of the product might be a determinant of the decision, as much as its taste and quality (Cassady et al., 2007; European Commission, 2010; Glanz et al., 1998). Although the consumers perceive the product as healthy, price becomes a barrier, especially for low-income consumers (Steenhuis et al., 2011).

Other highlights for the decision not to buy Petit-Suisse involve its composition and nutritional aspect. "Not being a healthy product," "Containing sugar," "High-fat content," "Added with additives and preservatives," and the fact that consumers deemed this cheese as an "Industrialized product" were the flagged negative aspects. These data are in line with 
the Ares et al. (2014) study on the perception of the wellbeing, which participants indicated Fat, Salt, Additives, Sugar and Manufacturing process as characteristics of food which harm their wellbeing. Since the '70s and '80s, the leading Brazilian manufacturer worked actively on campaigns that highlighted the nutritional value of this product by comparing it to a small steak. This fact emphasizes that the nutritional aspect has always been a desire of the consumer of this type of product, which may be associated with its destination to the infantile public. The industry should consider this consumer perception, to identify the points to be worked, such as deconstructing this image of the product, or creating variations that meet these requirements, expanding the target public. Wills et al. (2012) state that consumers' understanding of the product depends on independent consumer variables (such as their beliefs, familiarity, and nutritional knowledge), associated with independent product variables (such as taste, function, benefits, label), and converge on dependent variables of the consumer. The understanding of the appeal on the label, their attitude towards this appeal, lead to their attitude towards the product and purchase decision.

Some participants also indicated that they do not buy the product because they do "Not like it" (7.98\%) or "Prefer other foods" (6.08\%). In the Brazilian market, the product has only its traditional version, with a few variations of flavor. Besides, there are no options differentiated as to the nutritional value of the product, such as diet, light, lactose-free, functional or higher protein versions, for example, to explore other market niches.

The third and final stimulus provides insights into the possible future improvements of the product through the answer to the question: "I would buy if .... That is, what would arouse the interest of consumers in Petit-Suisse cheese that would lead to the purchase of the product. As expected, many of the points scored were the opposite of the score in the second stimulus. Among the points stood out: "Accessible price" (22.05\%), "More natural product" (13.31\%), "Less sugar" (7.60\%) and "Healthy" $(10.65 \%)$. However, some new categories provided deeper insights. "A wider variety of flavors and versions of this products" (11.03\%) was a suggested point, as different flavors and versions, diet, light, organic or lactose-free. Another interesting factor that was emphasized by the participants would be the "suitability of the packaging" (8.75\%). According to the surveyed, the product should be commercialized in larger portions, or the packaging information should aim to the adult audience. Moreover, finally, a portion of the participants, keep their consumption strictly related to the children's audience and only consume the product if they had children in the family (8.37\%).

In addition to understanding the perception of consumers about the product, the results confirm the importance of sensory analysis not only in the development of new products but also in the positioning of existing products in the market. In particular, the Completion Task proved to be a technique capable of raising important insights, both for research and for targeting marketing strategies across industries.

This type of study reinforces the importance and relevance of the application of projective methodologies, focused on consumer behavior, as a necessary part of sensory analysis of foods.

\section{Conclusions}

The present study showed that Petit-Suisse cheese is a dairy product with good acceptance in the Brazilian market. However, it is not recognized as a type of cheese, demonstrating a degree of unfamiliarity of the consumers with this product, which can be further explored by marketing.

The Completion Task was an essential tool for identifying consumers' classes with different perceptions about Petit-Suisse, as well as verifying effects of advertising, sensory and non-sensory characteristics and the consumer involvement with it and its intent to purchase.

Besides, one crucial aspect pointed out by consumers was the perception that Petit-Suisse is aimed exclusively to children and a very industrialized product. Thus, an expansion of the target public would be possible if the industry developed new products versions. More research is needed to investigate the influence of packaging on consumers' perception, as well as understand their perception of a healthy product, in order to overcome some of the limitations of the present work.

Lastly, the study highlighted that the dairy industry could explore different aspects of Petit-Suisse cheese. Identifying consumers' motivation to buy or not buy a product allows understanding consumers' needs and directing the industry towards the development of new product variations that already have a market demand. A better knowledge of the market intentions would enable the dairy industry to expand its market opportunities and provide a faster return of investments.

\section{References}

Ares, G., Saldamando, L., Giménez, A., \& Deliza, R. (2014). Food and wellbeing towards a consumer-based approach. Appetite, 74(47), 6169. http://dx.doi.org/10.1016/j.appet.2013.11.017. PMid:24295927.

Bimbo, F., Bonanno, A., Nocella, G., Viscecchia, R., Nardone, G., De Devitiis, B., \& Carlucci, D. (2017). Consumer's acceptance and preference for nutrition-modified and functional dairy products: a systematic review. Appetite, 113, 141-154. http://dx.doi.org/10.1016/j. appet.2017.02.031. PMid:28235616.

Brasil. Ministério da Agricultura e do Abastecimento. (2000). Aprova o Regulamento Técnico de Identidade e Qualidade de Queijo "PetitSuisse" (Instrução Normativa no 53 de 29 de dezembro de 2000). Diário Oficial [da] República Federativa do Brasil.

Busse, M., \& Siebert, R. (2018). The role of consumers in food innovation processes. European Journal of Innovation Management, 21(1), 20 43. http://dx.doi.org/10.1108/EJIM-03-2017-0023.

Cardarelli, H. R., Buriti, F. C. A., Castro, I. A., \& Saad, S. M. I. (2008). Inulin and oligofructose improve sensory quality and increase the probiotic viable count in potentially symbiotic petit-suisse cheese. LWT, 41, 1037-1046.

Cassady, D., Jetter, K. M., \& Culp, J. (2007). Is price a barrier to eating more fruit and vegetables for low-income families? Journal of the American Dietetic Association, 107(11), 1909-1915. http://dx.doi. org/10.1016/j.jada.2007.08.015. PMid:17964310.

Cesbron-Lavau, E., Lubrano-Lavadera, A. S., Braesco, V., \& Deschamps, E. (2017). Fromages blancs, petits-Suisses et laits fermentés riches em protéines. Fromages frais and high protein fermented milk. Cahiers de Nutrition et de Diététique, 52(1), 33-40. http://dx.doi. org/10.1016/j.cnd.2016.10.004. 
Dijksterhuis, G. (2016). New product failure: Five potential sources discussed. Trends in Food Science \& Technology, 50, 243-248.

Donoghue, S. (2000). Projective techniques in consumer research. Journal of Family Ecology and Consumer Science, 28, 47-53. http:// dx.doi.org/110.4314/jfecs.v28i1.52784

Eldesouky, A., Pulido, A. F., \& Mesias, F. J. (2015). The role of packaging and presentation format in consumer's preference for food: an application of projective techniques. Journal of Sensory Studies, 30(5), 360-369. http://dx.doi.org/10.1111/joss.12162.

Esmerino, E. A., Paixão, J. A., Cruz, A. G., Garitta, L., Hough, G., \& Bolini, H. M. (2015). Survival analysis: a consumer-friendly method to estimate the optimum sucrose level in probiotic petit Suisse. Journal of Dairy Science, 98(11), 7544-7551. http://dx.doi. org/10.3168/jds.2015-9651. PMid:26387013.

European Commission - EC. (2010). Food-related risks. Special Eurobarometer 354/Wave 73.5. Brussels: EC. Retrieved from https://ec.europa.eu/commfrontoffice/publicopinion/archives/ ebs/ebs_354_en.pdf

Food and Agriculture Organization of the United Nations - FAO. (2019). Dairy market review. Geneva: FAO. Retrieved from http:// www.fao.org/3/ca3879en/ca3879en.pdf

Gambaro, A. (2018). Projective techniques to study consumer perception of food. Current Opinion in Food Science, 21, 46-50. http://dx.doi. org/10.1016/j.cofs.2018.05.004.

Glanz, K., Basil, M., Maibach, E., Goldberg, J., \& Snyder, D. (1998). Why Americans eat what they do: taste, nutrition, cost, convenience, and weight control concerns as influences on food consumption. Journal of the American Dietetic Association, 98(10), 1118-1126. http://dx.doi.org/10.1016/S0002-8223(98)00260-0. PMid:9787717.

Guerrero, L. (1995). Does the consumer read and understand the product information? Product information and acceptability. In Proceedings of the Air-Cat Workshop (pp. 17-18). USA: Ames Research Center.

Guerrero, L., Claret, A., Verbeke, W., Enderli, G., Zakowska-Biemans, S., Vanhonacker, F., Issanchou, S., Sajdakowska, M., Granli, B. S., Scalvedi, L., Contel, M., \& Hersleth, M. (2010). Perception of traditional food products in six European regions using free word association. Food Quality and Preference, 21(2), 225-233. http:// dx.doi.org/10.1016/j.foodqual.2009.06.003.

Hovart, A., Granato, G., Fogliano, V., \& Luning, P. A. (2019). Understanding consumer data use in new product development and the product life cycle in Europeans food firms - an empirical study. Food Quality and Preference, (76), 20-32.

Johansen, S. B., Næs, T., \& Hersleth, M. (2011). Motivation for choice and healthiness perception of calorie-reduced dairy products. A cross-cultural study. Appetite, 56(1), 15-24. http://dx.doi.org/10.1016/j. appet.2010.11.137. PMid:21093506.

Johnson, M. E. (2017). A 100-year review: cheese production and quality. Journal of Dairy Science, 100(12), 9952-9965. http://dx.doi. org/10.3168/jds.2017-12979. PMid:29153182.

Judacewski, P., Los, P. R., Lima, L. S., Alberti, A., Zielinski, A. A. F., \& Nogueira, A. (2019). Perceptions of Brazilian consumers regarding white mould surface-ripened cheese using free word association. International Journal of Dairy Technology, 72(4), 585-590. http:// dx.doi.org/10.1111/1471-0307.12649.

Lin, W., Ortega, D. L., Caputo, V., \& Lusk, J. L. (2019). Personality traits and consumer acceptance of controversial food technology: A cross-country investigation of genetically modified animal products. Food Quality and Preference, 76, 10-19. http://dx.doi.org/10.1016/j. foodqual.2019.03.007.
Lopes, M. M. T., Rodrigues, M. C. P., \& Araújo, A. M. S. (2018). Influence of expectation measure on the sensory acceptance of Petit Suisse product. Journal of Food Science, 83(3), 798-803. http://dx.doi. org/10.1111/1750-3841.14067. PMid:29412461.

Meyerding, S. G. H., Trajer, N., \& Lehberger, M. (2019). What is local food? The case of consumer preferences for local food labeling of tomatoes in Germany. Journal of Cleaner Production, 207, 30-43. http://dx.doi.org/10.1016/j.jclepro.2018.09.224.

Pacheco, M. H. S., Kuriya, S. P., Capobiango, C. S. C., Pimentel, T. C., Cruz, A. G., Esmerino, E. A., \& Freitas, M. Q. (2018). Exploration of gender differences in bottled mineral water consumption: A projective study of consumers perceptions in Brazil. Journal of Sensory Studies, 33(4), e12434. http://dx.doi.org/10.1111/joss.12434.

Pinto, L. P. F., Silva, H. L., Kuriya, S. P., Maçaira, P. M., Cyrino Oliveira, F. L., Cruz, A. G., Esmerino, E. A., \& Freitas, M. Q. (2018). Understanding perceptions and beliefs about different types of fermented milks through the application of projective techniques: A case study using Haire's shopping list and free word association. Journal of Sensory Studies, 33(3), 1-8. http://dx.doi.org/10.1111/joss.12326.

Rocha, Y. J. P., Lapa-Guimarães, J., de Noronha, R. L. F., \& Trindade, M. A. (2018). Evaluation of consumers' perception regarding frankfurter sausages with different healthiness attributes. Journal of Sensory Studies, 33(6), e12468. http://dx.doi.org/10.1111/joss.12468.

Rojas-Rivas, E., Espinoza-Ortega, A., Martínez-Garcia, C. G., MoctezumaPérez, S., \& Thomé-Ortiz, H. (2018). Exploring the perception of Mexican urban consumers toward functional foods using the Free Word Association technique. Journal of Sensory Studies, 33(5), 1-11. http://dx.doi.org/10.1111/joss.12439.

Santiago-López, L., Aguilar-Toalá, J. E., Hernández-Mendoza, A., Vallejo-Cordoba, B., Liceaga, A. M., \& González-Córdova, A. F. (2018). Invited review: Bioactive compounds produced during cheese ripening and health effects associated with aged cheese consumption. Journal of Dairy Science, 101(5), 3742-3757. http:// dx.doi.org/10.3168/jds.2017-13465. PMid:29477517.

Sarmento, E. G., Cesar, D. E., Martins, M. L., de Oliveira Góis, E. G., Furtado Martins, E. M., da Rocha Campos, A. N., Del'Duca, A., \& de Oliveira Martins, A. D. (2018). Effect of probiotic bacteria in composition of children's saliva. Food Research International, 116, 1282-1288. http://dx.doi.org/10.1016/j.foodres.2018.10.017. PMid:30716917.

Sass, C. A., Kuriya, G. V., Silva, H. L. A., Silva, H. L. A., da Cruz, A. G., Esmerino, E. A., \& Freitas, M. Q. (2018). Completion task to uncover consumer's perception: a case study using distinct types of hen's eggs. Poultry Science, 97(7), 1-9. http://dx.doi.org/10.3382/ ps/pey103. PMid:29660079.

Songsamoe, S., Saengwong-Ngam, R., Koomhin, P., \& Matan, N. (2019). Understanding consumer physiological and emotional responses to food products using electroencephalography (EEG). Trends in Food Science \& Technology, 93, 167-173. http://dx.doi.org/10.1016/j. tifs.2019.09.018.

Steenhuis, I. H. M., Waterlander, W. E., \& de Mul, A.. (2011). Consumer food choice: the role of price and pricing strategies. Public Health Nutrition, 14(12), 2220-2226. http://dx.doi.org/10.1017/ S1368980011001637. PMid:21752312.

Stolzenbach, S., Bredie, W. L. P., \& Byrne, D. V. (2013). Consumer concept in new product development of local foods: Traditional versus novel honey. Food Research International, 52(1), 144-152. http://dx.doi.org/10.1016/j.foodres.2013.02.030.

Toloni, M. H. A., Longo-Silva, G., Konstantyner, T., \& Taddei, J. A. A. C. (2014). Consumption of industrialized food by infants attending child day care centers. Revista Paulista de Pediatria : Orgao Oficial da Sociedade de Pediatria de Sao Paulo, 32(1), 37-43. http://dx.doi. org/10.1590/S0103-05822014000100007. PMid:24676188. 
Veiga, P. G., Cunha, R. L., Viotto, W. H., \& Petenate, A. J. (2000). Caracterização química reológica e aceitação sensorial do queijo petit-suisse brasileiro. Food Science and Technology (Campinas), 20(3), 349-357. http://dx.doi.org/10.1590/S010120612000000300012.

Viana, M. M., Silva, V. L. S., Deliza, R., \& Trindade, M. A. (2016). The use of an online completion test to reveal important attributes in consumer choice: An empirical study on frozen burgers. Food Quality and Preference, 52, 255-261. http://dx.doi.org/10.1016/j.foodqual.2015.11.016.
Vidal, L., Ares, G., \& Giménez, A. (2013). Projective techniques to uncover consumer perception: application of three methodologies to ready-to-eat salads. Food Quality and Preference, 28(1), 1-7. http:// dx.doi.org/10.1016/j.foodqual.2012.08.005.

Wills, J. M., Bonsmann, S. S., Kolka, M., \& Grunet, K. G. (2012). Nutrition and health claims: help or hindrance European consumers and health claims: attitudes, understanding and purchasing behavior. In Proceedings of the Nutrition Society (Vol. 71, pp. 229-236). Cambridge: Cambridge University Press. 